\title{
The Investment Efficiency Of Private And Public Firms: Evidence From Korea
}

\author{
Keehwan Kim, Inil Accounting Corporation, South Korea
}

Ohjin Kwon, Sogang University, South Korea

\begin{abstract}
This study examines the investment efficiency of private and public firms in Korea. Prior studies suggest that the investment efficiency of firms can change according to the companies' agency problem caused by the existence of information asymmetry. Moreover, they argue that there is less information asymmetry in private firms than in public firms, because the major investors of private firms have access to the internal information of the companies. We extend these studies by comparing the investment efficiency of private and public firms using an extended audited financial dataset of Korean firms. Our results show that the investment efficiency of private firms is higher than that of public firms, because the agency problem of the former is lower than that of the latter. Additionally, private firms invest more efficiently in $R \& D$ and capital expenditures than public firms. Further, when we use alternative exogenous firm-specific proxies to measure the likelihood of over or under-investment, the results are substantially consistent with the main results. Finally, we re-test our hypotheses by including financial reporting quality proxies as control variables in the main regression model. These investigations further support our main results. Our study contributes to emerging literature on the difference between private and public firms by showing that the investment efficiency of the former is different from that of the latter. In addition, this study provides additional evidence on the agency problem that affects firms' investment decisions.
\end{abstract}

Keywords: Investment Efficiency; Agency Problem; Information Asymmetry; Private Firms; Public Firms

\section{INTRODUCTION}

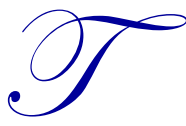

his study investigates the investment efficiency of private and public firms in Korea. Prior research has observed that investment efficiency could be affected by the agency problem caused by information asymmetry between managers and outside suppliers of capital (Jensen and Meckling, 1976; Myers, 1977; Myers and Majluf, 1984; Stein, 2003; McNichols and Stubben, 2008). In addition, Ball and Shivakumar (2005) and other studies argue that there is less information asymmetry in private firms than in public firms, because the former are more closely managed by shareholders and the major investors have access to the internal information of the companies (Beatty and Harris, 1998; Ball and Shivakumar, 2005; Burgstahler et al., 2006; Chen et al., 2011). According to these studies, we can expect the investment efficiency of private firms to be different from public firms. However, the influence of private ownership has been studied in limited contexts because financial data of private firms is not generally published (Givoly et al. 2010; Hope et al. 2013). Our study compares the investment behavior of Korean private and public firms using their extended audited financial dataset.

Prior studies show that publicly traded firms are different from private firms in several aspects, including ownership structure, and governance mechanism (Beatty and Harris, 1998; Ball and Shivakumar, 2005; Chen et al., 2011). In public firms, ownership and control must be separated as outside investors, who are not interested in management of the firms, hold majority of the company's shares. In this case, an agency problem can arise due to information asymmetry between the outside investors and managers (Jensen and Meckling, 1976). On the contrary, private firms are more likely to resolve the agency problem because the major investors, who often manage their own firms, have access to internal corporate information (Beatty and Harris, 1998; Ball and Shivakumar, 2005; Burgstahler et al., 2006; Chen et al., 2011). Further, private firms have highly concentrated ownership, with the 
lower shareholder turnover leading to higher monitoring of the top management by the owners, compared to public firms(and Shivakumar, 2005; Chen et al., 2011).

The literature also provides evidence suggesting that the information asymmetry between managers and outside capital providers can affect investment efficiency (Biddle et al. 2009; Cheng et al., 2013). Cheng et al.(2013) argue that moral hazard could provide managers with incentive to over-invest in order to maximize their own interests(Jensen, 1986; Stein, 2003). Under adverse selection, managers who are better informed than outside investors about the true value of firms are likely to sell overpriced shares. If they are successful, they may overinvest these proceeds (Biddle et al., 2009; Cheng et al., 2013). However, managers tend to under-invest if the cost of capital increases after rational investors anticipate the managers' intention to issue overpriced shares(Biddle et al., 2009; Cheng et al., 2013). These studies show that information asymmetry between managers and investors can result in over/ under-investment, thereby reducing investment efficiency.

According to previous studies, private firms, on average, have lower information asymmetry than public firms. Agency problems caused by this asymmetry induces firms to make inefficient investment decisions. Combining these findings from prior research, we conjecture that the level of information asymmetry has varying effects on the investment efficiency of private and public firms. However, most studies on corporate investment are based on evidence from public firms, because the accounting data of private firms is not easily available to the public. In this paper, we examine whether private firms invest more efficiently than publicly traded firms using a large dataset Korean firms. Therefore, we hypothesize that the investment efficiency of private firms is higher than that of public firms.

Korean financial reporting regulations provide ideal settings to compare private and public firms. First, the financial reporting and auditing regulations are equivalent for all public and private firms whose total assets exceed 10 million US dollars. According to the Korean Act on External Audit of Stock Companies, both public and private firms are required to submit their audit reports, including their ownership structure, that are available to users on their web site to the Financial Supervisory Commission. Finally, private and public firms are subject to the same tax laws. Korea, therefore, provides an opportunity to investigate the effect of ownership structure of companies.

Following Lawrence et al.(2011), we employ a propensity-score matching method to control for the differences in firm-specific characteristics between the private and public firms over the period 2004 to 2011. This procedure provides a public firm-year control sample that has similar characteristics to the private firm's sample, but has a different level of ownership structure and investment efficiency (Armstrong et al. 2010).

The empirical findings of the study are as follows. First, as hypothesized by us, private firms show higher investment efficiency than public firms, implying that information asymmetry can be mitigated in private firms, because investors play an instrumental role in the management of these firms and have more insider access to corporate information than in public companies. Robustness checks show that private firms invest more efficiently in $R \& D$ and capital expenditures than public firms. Further, private firms are less likely to invest when aggregate investment is high and more likely to invest when aggregate investment is low. This finding suggests that the privately owned firms are less affected by aggregate macro-economic volatility than public firms. Finally, we find that the main result does not change significantly after controlling for earnings quality in the model.

Our study makes the following contributions. First, this study extends prior research on the economically important differences of privately owned companies and publicly traded firms. Prior studies provide evidence that private equity firms have a different level of financial reporting quality than public equity firms, using a limited firm-year sample (Givoly et al. 2010; Beatty et al., 2002). However, we compare the investment behavior of private and public firms and suggest that the investment efficiency of private firms is higher than that of public firms using large audited financial data of Korean firms.

Second, this study provides additional evidence on the agency perspectives that affect investment efficiency. Cheng et al. (2013) suggest that financial reporting quality reduces agency costs, eventually leading firms to invest efficiently, using a sample of firms that disclosed internal control weakness (ICW) under the Sarbanes- 
Oxley Act. Using large audited financial data of private and public companies in Korea, this study provides further evidence that the agency problem caused by information asymmetry leads to inefficient investment.

The remainder of the paper is organized as follows. Section 2 reviews the related literature and develops the testable hypotheses. Section 3 discusses the research design. Section 4 presents the empirical results of the study. Finally, section 5 concludes the study.

\section{LITERATURE REVIEW AND HYPOTHESES}

\subsection{Privately Held Firms Versus Publicly Traded Firms}

Private firms have not been widely studied by researchers theoretically and empirically, although they form a substantial part of the global economy and the market demand for their financial reporting quality is substantially different from that for public companies' reporting quality(Ball and Shivakumar, 2005; Hope et al., 2013). Several researchers have been interested in the characteristics of private firms that are likely to list their stocks on the market. More recently, several others have also compared the financial reporting qualities of private and public companies (Welch, 1989; Teoh et al., 1998; Beatty et al., 2002; Givoly et al., 2010; Hope et al., 2013). Nevertheless, the private firms have received limited attention in academic research, especially in the study of their investment behavior.

Prior research argues that the agency problem caused by information asymmetry could be lower for private firms than for public firms (Beatty and Harris, 1998; Ball and Shivakumar, 2005; Burgstahler et al., 2006; Chen et al., 2011). In public firms, ownership is usually dispersed, with managers separately controlling the companies. In such case, agency costs are incurred because managers seek their own interests and outsider investors fail to monitor the management adequately (Jensen and Meckling, 1976). Additionally, the liquidity of public firms makes it easy for shareholders to sell their stock at the first sign of financial difficulties rather than actively monitoring management. This weakens incentives for internal monitoring and increases the agency problem (Bhide, 1993).

On the contrary, private companies are usually more closely held, and stockholders of the firms play an important role in management, leading to stricter monitoring of the managers (Ball and Shivakumar,2005). Furthermore, the firms are more likely to access informal internal information when contracting with other parties, rather than using public financial statements. Therefore, private companies can reduce information asymmetry between managers and investors by providing insider access (Ball and Shivakumar, 2005).

According to previous studies, the accounting literature has compared the financial reporting qualities of private and public companies (Beatty et al., 2002; Givoly et al., 2010; Hope et al., 2013). Beatty et al. (2002) suggest that public banks have more incentives to manipulate earnings because their shareholders are more likely to rely on earnings-based financial data to evaluate the firms' performance. Givoly et al. (2010) provide evidence that privately owned firms have higher accrual quality and lower income management than public companies. This is because the managers of public firms have greater incentive to manage earnings than those of private equity firms. On the other hand, Hope et al. (2013) find that public companies report higher accrual quality to meet the capital market demand, even though they create information asymmetry because of ownership dispersion and ownermanager separation. Ball and Shivakumar (2005) also show that the financial reporting quality of public companies is higher because they have a different market demand from private companies, as measured by timely loss recognition and accrual-based methods.

Previous research provides mixed results for the financial reporting quality of public and private firms. However, it is difficult to compare the current results because most of these studies use either small samples or limited samples including specialized industries, such as banking or private firms that issue public debt. On the contrary, Korean public and private firms whose total assets exceed 10 million US dollars are expected to file audited financial reports according to the same financial reporting and auditing regulations. Additionally, all firms have to file tax reports to the National Tax Service following the same tax laws. Therefore, the Korean sample provides an opportunity to examine the association between private and public companies. 


\subsection{Agency Problem and Investment Efficiency}

Cheng et al. (2013) argue that information asymmetry between managers and shareholders can result in adverse selection and moral hazard, affecting the optimal investment decisions of companies (Jensen and Meckling, 1976; Myers, 1977; Myers and Majluf, 1984; Stein, 2003; Biddle et al., 2009). Under adverse selection, managers who are better informed of the true value of their companies than outside investors can issue new stocks when the companies are overvalued. If investors do not monitor the manager's behavior, they can over-invest these proceeds (Biddle et al., 2009; Cheng et al., 2013). On the other hand, if outside investors respond rationally, thereby increasing the cost of capital, managers can refuse to raise the funds, eventually leading to under-investment.

Moreover, models of moral hazard suggest that managers are likely to maximize their own interests and may be inclined to make sub-optimal investment decisions. For example, Jensen (1986) proposes that managers have perquisite consumption and motivation to expand their firms beyond the optimal level. The managers are likely to provide upward-biased information to the board for approval of their investment plans. Thus, under moral hazard, firms with sufficient resources can over-invest. On the contrary, companies whose outside investors recognize the managers' behavior reject the investment plan, which may lead to under-investment ex-post (Biddle et al., 2009; Cheng et al., 2013).

Several recent studies have empirically examined investment decisions based on the agency approach. Richardson(2006) documents that the companies that have higher levels of free cash flow tend to over-invest, which is consistent with the explanations for agency costs. Further, the study finds that certain governance structure, such as the presence of active shareholders, affects the level of over-investment. Biddle and Hilary (2006) expect that investment efficiency is associated with information asymmetry and test whether financial reporting quality affects the firm-level capital investment efficiency by reducing agency costs. The study provides evidence that higher accounting quality enhances investment efficiency after mitigating investment-cash flow sensitivity. In addition, McNichols and Stubben(2008) suggest a positive relationship between financial reporting quality and investment efficiency, using a sample of firms accused of accounting improprieties by the U.S. Securities and Exchange Commission(SEC), identifying the period for which the manipulation is alleged. The study documents that managers do not choose optimal investment levels because they might be misinformed about the true state of their firms or growth trends of the market through manipulated financial reports. Biddle et al. (2009) argue that higher quality financial reports increase investment efficiency after reducing information asymmetry between managers and outside suppliers of capital, which saves cost of capital and monitoring costs. Finally, Cheng et al. (2013) document that firms that have disclosed their ICW in financial reporting systems are expected to reduce investment inefficiency in the post-disclosure period. This is because the ICW informs investors of adverse public signals and thus mitigates information asymmetry between managers and outside investors.

In summary, prior studies suggest that the company with high quality of financial reports can maintain an optimal level of investment by reducing information asymmetry between managers and outside capital providers (Verdi, 2006; Biddle and Hilary, 2006; McNichols and Stubben, 2008; Biddle et al., 2009; Cheng et al., 2013). In addition, the agency problem caused by information asymmetry could be lower in private firms than in public firms because private companies are usually closely held and stockholders of these firms play an important role in management. This, in turn, reduces the information asymmetry after the investors get access to inside information for making investment decisions (Beatty and Harris, 1998; Ball and Shivakumar, 2005; Burgstahler et al., 2006; Chen et al., 2011). Accordingly, we expect that private firms make investment decisions differently than publicly traded companies owing to the different level of information asymmetry. Based on the discussion above, we hypothesize that the private firms invest more efficiently than publicly traded firms. We thus propose the following two hypotheses:

$\mathbf{H}_{\mathbf{1 a}}$ : Private firms invest more than public firms do when the likelihood of under-investment is high.

$\mathbf{H}_{\mathbf{1 b}}$ : Private firms invest less than public firms do when the likelihood of over-investment is high. 


\section{RESEARCH DESIGN}

\subsection{Measurement of Investment Efficiency}

We compare the investment efficiency of private and public firms conditional on whether the firm is more likely to over- or under-invest. Consistent with Biddle et al. (2009), we use ex-ante firm-specific characteristics, such as liquidity that may affect the likelihood of over- or under-investment. We measure firm liquidity using two variables including cash balance and firm leverage as proxies for investment efficiency. First, firms with large cash balances are more likely to relate to inefficient use of the excessive cash that can lead to over-investment. Second, firms with low leverage are less likely to suffer financing constraints, and more likely to accept the current investment project. On the contrary, firms with small cash balances or high leverage are more likely to reject the investment plan that can cause under-investment.

The following model estimates whether private firms are negatively (or positively) related to investment efficiency when firms are more likely to over-invest (or under-invest) (firms subscripts are suppressed) (Biddle et al., 2009).

$$
\begin{aligned}
& \text { Investment }_{t+1}=\beta_{0}+\beta_{1} \text { ULIST }_{t}+\beta_{2} \text { OVER }_{U L I S T}+\beta_{3} \text { OVER }_{t}+\beta_{4} \text { SIZE }_{t}+\beta_{5} C F O_{t}+\beta_{6} \text { AGE }_{t}+ \\
& \beta_{7} \text { DIV }_{t}+\beta_{8} \text { LOSS }_{t}+\beta_{9} \text { CFOSales }_{t}+\beta_{10} \text { stdSALES }_{t}+\beta_{11} \text { stdCFO }_{t}+\beta_{12} \text { stdINV }_{t}+\beta_{13} \text { OPC }_{t}+\beta_{14} \text { Tangibility }_{t}+ \\
& \beta_{15} \text { INDlev }_{t}+\text { Industry dummies }+ \text { Year dummies }
\end{aligned}
$$

We estimate equation (1) using ordinary least square (OLS) regression after adjusting the standard errors for heteroskedasticity. The dependent variable Investment is the total investment measured as the sum of capital and R\&D expenditure multiplied by 100 and scaled by the lagged PPE. ULIST is an indicator variable which is one for private firms and zero for public firms. Consistent with Biddle et al. (2009), we measure Investment in Year $t+1$, and our indicator/ interaction variables and control variables at the end of Year $t$. A variable $O V E R$ distinguishes between firm characteristics in which the firm is more likely to over- or under-invest. To measure $O V E R$, we follow Biddle et al. (2009). First, we rank firms into deciles based on their cash to total asset ratio, and negative leverage at the end of Year $t$. Then, we average these two decile ranks and re-scale them to range from zero to one. In doing so, we can capture the likelihood of over-investment and increase the power of our analysis.

We test hypotheses $\mathrm{H}_{1 \mathrm{a}}$ and $\mathrm{H}_{1 \mathrm{~b}}$ by estimating equation (1) and focus on the indicator variable ULIST and the interaction variable $O V E R \_U L I S T$. If $O V E R$ equals zero, then firms suffer financial constraints and thus, are more likely to under-invest. Hypothesis $\mathrm{H}_{1 \mathrm{a}}$ predicts that private firms invest more than public firms do when the likelihood of underinvestment is high. We test this prediction by examining if the coefficient of ULIST is positive. On the other hand, if OVER equals one, then firms have the highest level of liquidity, and are more likely to over-invest. Hypothesis $\mathrm{H}_{1 \mathrm{~b}}$ predicts that private firms invest less than public firms do when the likelihood of over-investment is high. In this case, we test $\mathrm{H}_{1 b}$ by examining whether the sum of the coefficients $\left(\beta_{1}+\beta_{2}\right)$ of $U L I S T$ and $O V E R \_U L I S T$ is negative.

Control variables are included in equation (1). We base our control variables on Biddle et al. (2009), except for variables related to the stock market and governance because they are not available in private firms. Thus, our variables to control for investment behavior of firms include firm size (SIZE), cash flow from operation $(C F O)$, firm age (AGE), dividends indicator $(D I V)$, loss indicator (LOSS), cash flow deflated by sales (CFOsales), the standard deviation of sales (stdSALES), the standard deviation of cash flow from operations (stdCFO), the standard deviation of investment (stdINV), operation cycle $(O P C)$, tangibility (Tangibility), and industry leverage (INDlev). In addition, we consider the year dummies and industry dummies based on the two-digit Korean Standard Industry Codes.

\subsection{Propensity-Score Matching Model}

Private firms are substantially different from public firms in terms of unobservable innate characteristics as well as observable factors such as firm size, cash flow, and other factors that can influence the level of investment of the companies. To mitigate this concern, we employ the propensity-score matching model to control for unobservable differences in relevance dimension between private and public firms (Armstrong et al., 2010; Lawrence et al., 2011). Specifically, we estimate the propensity score in the first stage that includes all variables presenting determinants of investment in equation (2), as follows. 
LIST $_{t}=\beta_{0}+\beta_{1}$ SIZE $_{t}+\beta_{2}$ CFO $_{t}+\beta_{3}$ AGE $_{t}+\beta_{4}$ DIV $_{t}+\beta_{5}$ LOSS $_{t}+\beta_{6}$ CFOSales $_{t}+\beta_{7}$ StdSALES $_{t}+$ $\beta_{8}$ stdCFO $_{t}+\beta_{9}$ stdINV $_{t}+\beta_{10} O P C_{t}+\beta_{11}$ Tangibility $_{t}+\beta_{12}$ INDlev $_{t}+$ Industry dummies

In equation (2), we use a logit model to estimate the probability of being a public firm group for estimating propensity scores (Lawrence et al. 2011). Since the macro-economic situation changes every year, we estimate the logit model by year. We then match, without replacement, the public and private firm groups that have the closest predicted value from equation (2) within a maximum distance of 1 percent. After applying this process, we obtain propensity-score matched samples of 9,084 firm-years, which are 4,542 pairs in each private and public firm group. Finally, in the second stage, we estimate the coefficients in equation (1) using this sample to test the hypotheses $\mathrm{H}_{1 \mathrm{a}}$ and $\mathrm{H}_{1 \mathrm{~b}}$.

\subsection{Sample Selection}

For our analysis, we use private and public firm-year data from 2004 to 2011 . We restrict our test to this period because several control variables are missing in the earlier private firm-year samples. The financial data for private and public firms are collected from the KIS-VALUE database, which provides all audited Korean companies' financial reports. Consistent with prior studies, we exclude financial firms because the nature of investment for these firms differs from those of other firms. Therefore, we use nonfinancial firms with available data requiring at least 20 observations in each two-digit Korean Industry Classification Code grouping per year. After truncating extreme observations at the top and bottom 1 percent of all the variables in the model except indicator variables, in order to mitigate the influence of outliers, the sample size is reduced to 44,907 firm-year observations over the period. Finally, we use 9,084 firm- year samples after matching private and public firm-year samples according to the propensity-score matching process.

\section{EMPRICAL RESULTS}

\subsection{Univariate Test}

Table 1 presents the descriptive statistics for the variables in equation (1). Our sample contains 9,084 firmyear observations, which include 4,542 private and public firms for the period 2004 to 2011. Columns $2-5$ of Table 1 provide the mean, median and standard deviation for our dependent and control variables of full matched sample. On average, our sample firms invest about 38.69 percent of lagged PPE. The mean of firm size (SIZE) across all firm-years is 25.22 , which is equal to about 171 million US dollars.

Columns 6 -9 of Table 1 provide descriptive statistics of private firm observations, and columns $10-13$ of Table 1 provide the statistics of public firm observations. The mean of private firms' Investment equals 34.21, which is smaller than the mean of public firms' Investment at the one percent level. This implies that public firms, on average, invest more than private firms. On the contrary, the average firm size (SIZE) of private firms is bigger than that of public companies at the ten percent level, even though both are matched by propensity score using equation (2). In addition, the mean of firm age (AGE) and industry leverage (INDlev) between private and public firms is different from each other at one percent level and the five percent level, respectively. However, other variables do not represent significant differences between private and public firms as a result of the propensity-score matching process. 


\begin{tabular}{|c|c|c|c|c|c|c|c|c|c|c|c|c|c|c|}
\hline \multirow[b]{2}{*}{ (1)Variables } & \multicolumn{4}{|c|}{ Full sample $(\mathrm{N}=9,084)$} & \multicolumn{4}{|c|}{ Private firms $(\mathrm{N}=4,542)$} & \multicolumn{4}{|c|}{ Pubic firms $(\mathrm{N}=4,542)$} & \multicolumn{2}{|c|}{ Private-Public firms } \\
\hline & (2)OBS & (3)Mean & (4)Median & $\begin{array}{l}\text { (5)Std. } \\
\text { dev. }\end{array}$ & (6)OBS & (7)Mean & (8)Median & $\begin{array}{c}\text { (9)Std. } \\
\text { dev. }\end{array}$ & (10)OBS & (11)Mean & $\begin{array}{c}\text { (12)Media } \\
\text { n }\end{array}$ & $\begin{array}{c}\text { (13)Std. } \\
\text { dev. }\end{array}$ & $\begin{array}{l}\text { (14)Diff. } \\
\text { in Mean }\end{array}$ & (15)t-stat \\
\hline Investment & 9,084 & 38.685 & 15.506 & 84.128 & 4,542 & 34.206 & 13.752 & 73.610 & 4,542 & 43.164 & 17.180 & 93.264 & -8.958 & $-5.080^{* * *}$ \\
\hline SIZE & 9,084 & 25.220 & 25.107 & 1.064 & 4,542 & 25.241 & 25.116 & 1.178 & 4,542 & 25.198 & 25.104 & 0.935 & 0.042 & $1.900^{*}$ \\
\hline CFO & 9,084 & 0.045 & 0.045 & 0.153 & 4,542 & 0.043 & 0.045 & 0.167 & 4,542 & 0.046 & 0.043 & 0.138 & -0.003 & -0.980 \\
\hline$A G E$ & 9,084 & 3.094 & 3.135 & 0.559 & 4,542 & 3.108 & 3.135 & 0.535 & 4,542 & 3.081 & 3.135 & 0.581 & 0.027 & $2.320^{* *}$ \\
\hline$D I V$ & 9,084 & 0.519 & 1.000 & 0.500 & 4,542 & 0.526 & 1.000 & 0.499 & 4,542 & 0.512 & 1.000 & 0.500 & 0.013 & 1.280 \\
\hline$B I G$ & 9,084 & 0.461 & 0.000 & 0.498 & 4,542 & 0.477 & 0.000 & 0.500 & 4,542 & 0.444 & 0.000 & 0.497 & 0.033 & $3.180^{\text {**** }}$ \\
\hline LOSS & 9,084 & 0.240 & 0.000 & 0.427 & 4,542 & 0.233 & 0.000 & 0.423 & 4,542 & 0.247 & 0.000 & 0.431 & -0.014 & -1.570 \\
\hline CFOsale & 9,084 & 0.024 & 0.046 & 0.503 & 4,542 & 0.019 & 0.048 & 0.580 & 4,542 & 0.029 & 0.043 & 0.413 & -0.009 & -0.900 \\
\hline stdSALES & 9,084 & 0.297 & 0.210 & 0.286 & 4,542 & 0.299 & 0.216 & 0.282 & 4,542 & 0.295 & 0.204 & 0.290 & 0.005 & 0.810 \\
\hline$s t d C F O$ & 9,084 & 0.085 & 0.069 & 0.068 & 4,542 & 0.086 & 0.070 & 0.068 & 4,542 & 0.085 & 0.069 & 0.068 & 0.001 & 0.790 \\
\hline$s t d I N V$ & 9,084 & 6.463 & 3.788 & 11.654 & 4,542 & 6.494 & 3.592 & 13.801 & 4,542 & 6.432 & 3.988 & 9.010 & 0.063 & 0.260 \\
\hline$O P C$ & 9,084 & 4.722 & 4.766 & 0.793 & 4,542 & 4.718 & 4.757 & 0.854 & 4,542 & 4.725 & 4.779 & 0.726 & -0.007 & -0.420 \\
\hline Tangibility & 9,084 & 0.303 & 0.283 & 0.195 & 4,542 & 0.302 & 0.276 & 0.205 & 4,542 & 0.303 & 0.290 & 0.186 & -0.001 & -0.310 \\
\hline INDlev & 9,084 & 0.527 & 0.523 & 0.061 & 4,542 & 0.529 & 0.524 & 0.063 & 4,542 & 0.524 & 0.520 & 0.060 & 0.006 & $4.390^{* * * *}$ \\
\hline
\end{tabular}

This table presents the descriptive statistics for the variables used in the sample (9,084 firm-year observations) including the listed firms on the Korea Composite Stock Price Index (KOSPI), the Korea Securities Dealer Automated Quotation (KOSDAQ) market, Korea New Exchange (KONEX) market and private firms over the period 2004 to 2011. See the Appendix for variable definitions.

Table 2. Correlation Matrix (N=9,084)

\begin{tabular}{|c|c|c|c|c|c|c|c|c|c|c|c|c|c|c|c|}
\hline Variables & Investment & Ulist & OVER & SIZE & CFO & $A G E$ & DIV & LOSS & CFOsale & stdSALES & stdCFO & stdINV & $O P C$ & Tangibility & INDlev \\
\hline Investment & & -0.05 & 0.13 & -0.10 & 0.04 & -0.17 & -0.05 & 0.02 & 0.01 & 0.07 & 0.14 & 0.03 & 0.01 & -0.33 & -0.04 \\
\hline Ulist & -0.09 & & -0.01 & 0.02 & -0.01 & 0.02 & 0.01 & -0.02 & -0.01 & 0.01 & 0.01 & 0.00 & 0.00 & 0.00 & 0.05 \\
\hline OVER & 0.14 & -0.02 & & -0.21 & 0.22 & -0.06 & 0.21 & -0.20 & 0.10 & -0.02 & 0.00 & -0.10 & -0.06 & -0.28 & -0.16 \\
\hline SIZE & -0.07 & 0.00 & -0.21 & & 0.08 & 0.08 & 0.12 & -0.18 & 0.03 & -0.06 & -0.12 & -0.05 & -0.11 & 0.11 & 0.15 \\
\hline$C F O$ & 0.17 & 0.02 & 0.28 & 0.11 & & -0.01 & 0.25 & -0.29 & 0.56 & -0.05 & -0.12 & -0.01 & -0.19 & 0.08 & -0.04 \\
\hline$A G E$ & -0.27 & 0.02 & -0.08 & 0.13 & -0.05 & & 0.11 & -0.08 & 0.02 & -0.26 & -0.20 & -0.15 & -0.03 & 0.13 & 0.02 \\
\hline$D I V$ & 0.05 & 0.01 & 0.20 & 0.13 & 0.32 & 0.11 & & -0.48 & 0.12 & -0.05 & -0.13 & -0.08 & -0.08 & 0.01 & -0.02 \\
\hline LOSS & -0.10 & -0.02 & -0.20 & -0.18 & -0.37 & -0.08 & -0.48 & & -0.16 & 0.03 & 0.10 & 0.09 & 0.06 & 0.05 & 0.03 \\
\hline CFOsales & 0.10 & 0.03 & 0.31 & 0.12 & 0.91 & -0.03 & 0.28 & -0.35 & & -0.07 & -0.11 & -0.04 & -0.15 & 0.05 & -0.03 \\
\hline stdSALES & 0.15 & 0.01 & -0.05 & -0.11 & -0.03 & -0.31 & -0.09 & 0.05 & -0.11 & & 0.27 & 0.10 & -0.12 & -0.12 & 0.07 \\
\hline$s t d C F O$ & 0.16 & 0.01 & 0.00 & -0.15 & -0.07 & -0.24 & -0.15 & 0.12 & -0.13 & 0.37 & & 0.15 & 0.02 & -0.17 & 0.04 \\
\hline stdINV & 0.19 & -0.06 & -0.12 & -0.10 & 0.06 & -0.17 & -0.05 & 0.06 & 0.03 & 0.13 & 0.13 & & -0.03 & 0.18 & 0.06 \\
\hline$O P C$ & 0.02 & -0.01 & -0.04 & -0.13 & -0.21 & -0.02 & -0.07 & 0.05 & -0.14 & -0.14 & 0.00 & -0.05 & & -0.13 & -0.23 \\
\hline Tangibility & -0.35 & -0.02 & -0.26 & 0.09 & 0.09 & 0.16 & 0.03 & 0.03 & 0.10 & -0.15 & -0.21 & 0.31 & -0.12 & & 0.07 \\
\hline INDlev & -0.10 & 0.04 & -0.14 & 0.17 & -0.06 & 0.06 & 0.00 & 0.01 & -0.07 & 0.05 & 0.01 & -0.04 & -0.23 & 0.01 & \\
\hline
\end{tabular}

This table presents Pearson (Spearman) correlations above (below) the diagonal for variables. Coefficients shown in bold are significant at $\mathrm{p}<0.05$ (two-tailed test). See the Appendix for variable definitions. 
Table 2 provides the correlations among dependent and control variables. Our indicator variable, ULIST $(O V E R)$ is negatively (positively), and significantly related to Investment. However, as described below, ULIST is related to Investment conditionally on the firms' liquidity level, which represents their propensity to over- or underinvestment. Firm age (AGE) and cash flow (CFOsales) are significantly related to firms' investment decision (Investment). On the other hand, other control variables are not likely to be significantly related to Investment. The liquidity level of companies $(O V E R)$ is related to several control variables such as firm age (AGE), dividends (DIV), loss (LOSS), cash flow (CFOsales) and other firm characteristics.

\subsection{Multivariate Results}

Table 3 provides the main results for our conditional tests of hypotheses $\mathrm{H}_{1 \mathrm{a}}$ and $\mathrm{H}_{1 \mathrm{~b}}$. The dependent variable is Investment. The results are based on the propensity-score matched sample in Year $t$. The coefficient of private firms (ULIST) is +12.756 at the significant one percent level. This suggests that private firms invest significantly more than public firms do when the likelihood of under-investment is high. This result is consistent with hypothesis $\left(\mathrm{H}_{1 \mathrm{a}}\right)$.

Table 3. Conditional relation between investment and private firms

\begin{tabular}{|c|c|c|c|}
\hline (1) Variables & (2) Predicted Sign & (3) Coefficient & (4) t-value \\
\hline ULIST & $+/-$ & 12.756 & $4.14^{* * * * *}$ \\
\hline OVER_ULIST & $+/-$ & -41.561 & $-6.15^{* * *}$ \\
\hline OVER & $+/-$ & 28.235 & $4.78^{* * *}$ \\
\hline$S I Z E$ & - & -3.390 & $-3.84^{* * *}$ \\
\hline CFO & + & 47.170 & $6.12^{* * *}$ \\
\hline$A G E$ & - & -13.590 & $-8.98^{* * *}$ \\
\hline$D I V$ & - & -4.370 & $-2.33^{* *}$ \\
\hline LOSS & - & 4.296 & $1.68^{*}$ \\
\hline CFOsale & + & -1.673 & -0.85 \\
\hline stdSALES & - & -8.757 & $-2.68^{* * *}$ \\
\hline stdCFO & + & 65.793 & $3.45^{* * *}$ \\
\hline stdINV & + & 0.424 & $4.23^{* * *}$ \\
\hline$O P C$ & - & -1.971 & -1.12 \\
\hline Tangibility & - & -131.943 & $-21.94^{* * *}$ \\
\hline INDlev & - & -84.130 & $-3.01^{* * * *}$ \\
\hline Fixed Effect & & \multicolumn{2}{|c|}{ Year and Industry } \\
\hline Observations & & \multicolumn{2}{|c|}{9,084} \\
\hline adj R-square & & \multicolumn{2}{|c|}{0.161} \\
\hline F-value & & \multicolumn{2}{|c|}{$35.58^{* * * *}$} \\
\hline F-test: & & Coefficient & F-value \\
\hline $\begin{array}{l}\text { Joint significance } \\
(\text { ULIST+OVER_ULIST) }\end{array}$ & & -28.805 & $66.59^{* * *}$ \\
\hline
\end{tabular}

This table presents the regression estimates of the model that examines the relation between private firms (ULIST) and total investment (Investment) based on the propensity-score matched sample. The model includes year and industry fixed effects based on the two-digit Korean Standard Industry Codes. $T$-statistics are corrected for heteroskedasticity. ***, **, and * denote statistical significance at $1 \%$, $5 \%$, and $10 \%$ levels respectively, based on two-tailed test. See the Appendix for variable definitions.

The coefficient of interaction variables (OVER_ULIST) is -41.561 and is significantly negative at the one percent level. This result means that private firms are more likely to decrease incremental investment when the firms' liquidity level is increasing. To test hypothesis $\left(\mathrm{H}_{1 b}\right)$, as discussed before, we are interested in the sum of the coefficients of private firms (ULIST), and the interaction between private firms and liquidity level (OVER_ULIST). Our results show that the sum of $\beta_{1}$ and $\beta_{2}$ is -28.805 , and is significantly negative at the one percent level. These findings are consistent with hypothesis $\left(\mathrm{H}_{1 \mathrm{~b}}\right)$, suggesting that private firms invest significantly less than public firms do when the likelihood of over-investment is high.

Results for the control variables are generally consistent with previous studies, such as Biddle et al. (2009) and Cheng et al. (2013). First, firm size (SIZE) is negatively related to investment (Investment) at the one percent level because the investment opportunity of big companies is relatively less than that of small companies, which are more likely to try to find new growth opportunities. Cash flow is the most important determinant to decide the investment. Thus, cash flow from operations (CFO), and the volatility of cash flow (stdCFO) are positively 
associated with the dependent variable (Investment) at the one percent level. Firm age (AGE) is negatively related to investment (Investment) because young companies apparently find new investment opportunities rather than old companies. Further, dividends $(D I V)$ and tangibility (Tangibility) exhibit a negative relationship with investment (Investment), which corresponds to the results obtained by Biddle et al. (2009), and Cheng et al. (2013).

Overall, our results show that the investment efficiency of private firms is higher than that of public firms, supporting both $\mathrm{H}_{1 \mathrm{a}}$ and $\mathrm{H}_{1 \mathrm{~b}}$. It implies that information asymmetry can be mitigated in private firms, because investors play an important role in the management of these firms and have more access to internal information than in public companies.

\subsection{Additional Analyses}

\subsubsection{Capital Expenditures and Non-Capital Expenditures}

We analyze the investment efficiency of private and public firms in the partitioned liquidity situation as described in Table 3. As discussed before, we include both capital and non-capital expenditures when we calculate total investment. This measure of investment follows Biddle et al. (2009), and Richardson (2006). In order to check for robustness, we decompose the total investment into two components (Biddle et al., 2009; Cheng et al., 2013). Table 4 provides the results after the dependent variable Investment is decomposed into two components, Capex and Non-Capex, as alternative dependent variables. We compute Capex as current capital expenditures scaled by lagged PPE and multiplied by 100, while Non-Capex is computed as current R\&D expenditures scaled by lagged PPE, and multiplied by 100 . We re-test our main hypotheses using these two proxies.

Results reported in Table 4 show that our main hypotheses are not affected by the decision to use either Capex or Non-Capex as the dependent variable. Columns 2-3 of Table 4 provide the estimated coefficients when the dependent variable is Capex, and columns $4-5$ of Table 4 represent the results in case of Non-Capex. The main effects of private firms (ULIST) on the Capex and Non-Capex are positive and significant at the five percent level and the one percent level, respectively (the $t$-statistics equal 2.01 and 3.41, respectively). Our results show that private firms incur more capital as well as $R \& D$ expenditures than public firms do when the likelihood of underinvestment is high. These results provide robust evidence to support hypothesis $\left(\mathrm{H}_{1 \mathrm{a}}\right)$.

Furthermore, the interaction terms (OVER_ULIST) between ULIST and OVER are negative and significant at the one percent level (with $t$-statistics of -3.84 and -4.52 , respectively). These are substantially consistent with the results in Table 3. In addition, the sum of the coefficients $\left(\beta_{1}+\beta_{2}\right)$ of ULIST and on the interaction(OVER_ULIST) between ULIST and OVER is -15.184 and -5.512 at the one percent level, respectively. These results also suggest that when the likelihood of over-investment is high, the private firms incur significantly less capital as well as non-capital expenditures than public firms do. These findings are consistent with hypothesis $\left(\mathrm{H}_{1 b}\right)$. The coefficients of control variables show substantially the same results as in Table 4, even though the significance of several control variables in columns $4-5$ disappears.

Overall, even when we use either capital expenditure (or non-capital expenditure) as the dependent variable, our results show that investment efficiency of private firms is higher than that of public firms. These results are consistent with our main results as reported in Table 3. 
Table 4. Results for Alternative Dependent Measure: Capex and Non-Capex

\begin{tabular}{|c|c|c|c|c|}
\hline \multirow[b]{2}{*}{$\begin{array}{c}\text { Variables } \\
\text { (1) }\end{array}$} & \multicolumn{2}{|c|}{ Capex } & \multicolumn{2}{|c|}{ Non-Capex } \\
\hline & $\begin{array}{c}\text { Coefficient } \\
\text { (2) }\end{array}$ & $\begin{array}{l}\text { t-value } \\
(3)\end{array}$ & $\begin{array}{l}\text { Coefficient } \\
\text { (4) }\end{array}$ & $\begin{array}{l}\text { t-value } \\
(5)\end{array}$ \\
\hline ULIST & 4.834 & $2.01^{* * *}$ & 3.009 & $3.41^{* * * *}$ \\
\hline OVER_ULIST & -20.019 & $-3.84^{* * *}$ & -8.521 & $-4.52^{* * * *}$ \\
\hline OVER & 14.264 & $3.17^{* * *}$ & 6.396 & $4.07^{* * * *}$ \\
\hline SIZE & -3.343 & $-5.57^{* * *}$ & -0.365 & -1.48 \\
\hline$C F O$ & 38.437 & $6.55^{* * *}$ & 3.696 & 1.23 \\
\hline$A G E$ & -9.858 & $-8.24^{* * *}$ & -3.525 & $-7.64^{* * * *}$ \\
\hline$D I V$ & -3.992 & $-3.08^{* * *}$ & -0.602 & -1.12 \\
\hline LOSS & 0.811 & 0.47 & 1.078 & 1.64 \\
\hline CFOsale & -1.531 & -1.07 & 0.071 & 0.15 \\
\hline stdSALES & -2.333 & -1.08 & -1.500 & -1.81 \\
\hline stdCFO & 18.158 & 1.50 & 11.073 & $2.53^{* *}$ \\
\hline$s t d I N V$ & 0.421 & $4.54^{* * *}$ & 0.000 & 0.03 \\
\hline$O P C$ & -1.925 & -1.75 & 0.486 & 1.49 \\
\hline Tangibility & -88.579 & $-21.35^{* * *}$ & -25.993 & $-17.00^{* * * *}$ \\
\hline INDlev & -48.355 & $-2.41^{* * *}$ & -28.433 & $-3.84^{* * * *}$ \\
\hline Fixed Effect & \multirow{4}{*}{\multicolumn{2}{|c|}{$\begin{array}{c}\text { Year and Industry } \\
9,084 \\
0.154 \\
32.79^{* * *}\end{array}$}} & \multirow{4}{*}{\multicolumn{2}{|c|}{$\begin{array}{c}\text { Year and Industry } \\
9,084 \\
0.126 \\
25.93^{* * *}\end{array}$}} \\
\hline Observations & & & & \\
\hline adj R-square & & & & \\
\hline F-value & & & & \\
\hline F-test : & Coefficient & F-value & Coefficient & F-value \\
\hline $\begin{array}{l}\text { Joint significance } \\
(\text { ULIST+OVER_ULIST) }\end{array}$ & -15.184 & $9.38^{* * * *}$ & -5.512 & $32.99^{* * * *}$ \\
\hline
\end{tabular}

This table presents the regression estimates of the model that examines the relation between private firms (ULIST) and Capex (Non-Capex) investment based on the propensity-score matched sample. Columns $2-3$ provide the estimated coefficients when the dependent variable is Capex, and columns $4-5$ represent the estimated coefficients when the dependent variable is Non-Capex. The model includes year and industry fixed effects based on based on the two-digit Korean Standard Industry Codes. T-statistics are corrected for heteroskedasticity. $* * *, * *$, and $*$ denote statistical significance at $1 \%, 5 \%$, and $10 \%$ levels respectively, based on two-tailed test. See the Appendix for variable definitions.

\subsubsection{Partitioning Variables at the Aggregate and Industry Levels as a Proxy for Over}

Biddle et al. (2009) propose exogenous firm-specific proxies to measure the likelihood of over- or underinvestment, instead of measures based on cash (or leverage) (OVER). They use investment aggregated at the economy and industry levels because aggregate investment is less likely to be affected by firm specific characteristics that cause endogenous problems in the regression equation (1). Following Biddle et al. (2009), we use the new proxies of aggregated invest measures to provide robust evidence of our previous results. In addition, we estimate the likelihood of over- or under-investment measure based on the industry aggregated level (OverIndustry), and overall economy aggregated level (OverAggregate) using equation (3).

Investment $_{t+1}=\beta_{0}+\beta_{1}$ SalesGrowth $_{t}$

To measure OverIndustry, we estimate $\beta_{1}$ in equation (3) using the average Investment and average SalesGrowth for all industries with at least 20 observations in each two-digit Korean Industry Classification Code grouping per year. Then we rank the estimated residuals from equation (3) into deciles, which are re-scaled from zero to one. Finally, we re-estimate equation (1) using new measures as OverIndustry instead of OVER. In addition, we use the average Investment and average SalesGrowth in the overall economy to estimate residual from equation (3) in a given year. Then, we rank the residuals into deciles, and use the deciles as the proxy for aggregated likelihood of over-investment in each year, OverAggregate. 
Table 5. Aggregate over-investment partitions.

\begin{tabular}{|c|c|c|c|c|}
\hline \multirow{2}{*}{$\begin{array}{c}\text { Variables } \\
\text { (1) }\end{array}$} & \multicolumn{2}{|c|}{ Over $=$ OverIndustry } & \multicolumn{2}{|c|}{ Over $=$ OverAggregate } \\
\hline & $\begin{array}{c}\text { Coefficient } \\
\text { (2) }\end{array}$ & $\begin{array}{c}\text { t-value } \\
(3)\end{array}$ & $\begin{array}{c}\text { Coefficient } \\
(4)\end{array}$ & $\begin{array}{c}\text { t-value } \\
(5)\end{array}$ \\
\hline ULIST & 3.446 & $1.74^{*}$ & 10.866 & $4.30^{* * * * 2}$ \\
\hline OVER_ULIST & -15.029 & $-2.39^{* *}$ & -23.993 & $-3.47^{* * * *}$ \\
\hline OVER & 151.865 & $28.16^{* * *}$ & 145.269 & $29.04^{* * * *}$ \\
\hline SIZE & -2.695 & $-3.53^{* * *}$ & -3.854 & $-4.73^{* * * *}$ \\
\hline$C F O$ & 23.246 & $3.82^{* * *}$ & 19.590 & $3.08^{* * * *}$ \\
\hline$A G E$ & -5.701 & $-4.52^{* * * *}$ & -4.800 & $-3.42^{* * * *}$ \\
\hline$D I V$ & -7.605 & $-4.64^{* * *}$ & -8.905 & $-5.15^{* * * *}$ \\
\hline LOSS & 3.152 & 1.47 & 6.574 & $2.81^{* * *}$ \\
\hline CFOsale & -1.620 & -1.17 & 0.051 & 0.04 \\
\hline stdSALES & -11.634 & $-4.25^{* * *}$ & -8.993 & $-3.42^{* * * *}$ \\
\hline$s t d C F O$ & 38.087 & $2.35^{* *}$ & 48.205 & $3.00^{* * * *}$ \\
\hline stdINV & 0.253 & $3.85^{* * *}$ & 0.130 & $2.60^{* * *}$ \\
\hline$O P C$ & -2.072 & -1.38 & -1.475 & -1.14 \\
\hline Tangibility & -70.121 & $-18.46^{* * *}$ & -63.400 & $-16.42^{* * *}$ \\
\hline INDlev & -357.188 & $-13.09^{* * *}$ & -48.888 & $-1.96^{* *}$ \\
\hline Fixed Effect & \multirow{4}{*}{\multicolumn{2}{|c|}{$\begin{array}{c}\text { Year and Industry } \\
9,084 \\
0.392 \\
117.98^{* * *}\end{array}$}} & \multirow{4}{*}{\multicolumn{2}{|c|}{$\begin{array}{c}\text { Year and Industry } \\
9,470 \\
0.321 \\
88.80^{* * *}\end{array}$}} \\
\hline Observations & & & & \\
\hline adj R-square & & & & \\
\hline F-value & & & & \\
\hline F-test : & Coefficient & F-value & Coefficient & F-value \\
\hline $\begin{array}{l}\text { Joint significance } \\
(\text { ULIST+OVER ULIST) }\end{array}$ & -11.582 & $19.72^{* * *}$ & -13.127 & $23.02^{* * * *}$ \\
\hline
\end{tabular}

This table presents the regression estimates of the model that examines the relation between private firms (ULIST) and total investment (Investment) based on the propensity-score matched sample. Columns 2-3 provide the estimated coefficients using industry partitioning and columns 4-5 represent the estimated coefficients using aggregate economy partitioning. The model includes year and industry fixed effects based on based on two-digit Korean Standard Industry Codes. T-statistics are corrected for heteroskedasticity. $* * *, * *$, and $*$ denote statistical significance at $1 \%, 5 \%$, and $10 \%$ levels respectively, based on two-tailed test. See the Appendix for variable definitions.

Results reported in Table 5 show that our main hypotheses are not substantially changed after using alternative proxies for the likelihood of over- or under-investment measures. Columns $2-3$ of Table 5 provide the estimated coefficients using the industry partitioning and columns $4-5$ of Table 5 represent results using aggregate economy partitioning. The coefficients of ULIST are significantly positive at the ten percent level and the one percent level, respectively (the $t$-statistics equal 1.74 and 4.30 , respectively). These results provide additional evidence on hypothesis $\mathrm{H}_{1 \mathrm{a}}$ that private firms usually increase investment more than public firms when the liquidity condition measured using alternative aggregated proxy is the worst. In addition, the coefficients of the interaction terms (OVER_ULIST) between ULIST and OVER are significantly negative at the five percent level and the one percent level, respectively (with $t$-statistics of -2.39 and -3.47 , respectively). The sum of the coefficients of ULIST and OVER_ULIST is -11.582 and -13.127 at the one percent level, respectively. These results also provide robust evidence for hypothesis $\mathrm{H}_{1 \mathrm{~b}}$ that the private firms invest less than public firms do when the likelihood of over-investment is high. Additionally, these findings suggest that private firms are less likely to be affected by overall economy shocks in investment decision than public firms are.

\subsubsection{Financial Reporting Quality Measures}

Previous studies document that higher financial reporting quality increases the investment efficiency by reducing information asymmetry between managers and outside investors (Verdi, 2006). Moreover, private and public firms usually provide different qualities of financial reports due to different market demand (Beatty, 2002). According to related studies, financial reporting quality of private or public companies can affect our main results for investment efficiency. To mitigate this concern, we include financial reporting quality proxies in equation (1).

We use two proxies to control for financial reporting quality. First, we add the absolute value of discretionary accruals commonly used to examine financial reporting quality literature. We estimate a cross- 
sectional variant of the Jones (1991) model modified by Dechow et al. (1995). Second, we also use earnings quality measure, modified by Francis et al (2005). The model proposed by Dechow and Dichev(2002), and Francis et al. (2005) include changes in sales and PPE.

Table 6 reports the results for equation (1) after including financial reporting quality proxies. Columns 2 3 of Table 6 provide the results using the modified Jones model and columns $4-5$ of Table 6 show the results using earnings quality measure. Our results show that the sign of ULIST is significantly positive for both measures (with $t$ statistics of 4.27 and 3.94, respectively). Further, the sum of the coefficients of ULIST and OVER_ULIST is -28.538 and -27.362 at the one percent level, respectively. These results, which strongly support hypothesis $\mathrm{H}_{1 \mathrm{a}}$ and $\mathrm{H}_{1 \mathrm{~b}}$, show that the investment efficiency of private firms is higher than that of public firms.

\section{CONCLUSION}

Earlier studies document that the investment efficiency of firms can change according to the companies' agency problems caused by information asymmetry between managers and outside investors. Moreover, private and public firms have different levels of information asymmetry because the former are more closely managed by shareholders and their major investors have access to internal information of the companies. We extend these studies by comparing the investment efficiency of private and public firms using an extended audited financial dataset of Korean firms. We hypothesize that the private firms invest more efficiently than public firms.

Our results support the hypothesis that the investment efficiency of private firms is higher than that of public firms because the agency problem caused by information asymmetry of private firms is lower than that of public firms. Robustness checks show that private firms invest more efficiently in R\&D and capital expenditures than public firms. Further, we use alternative exogenous firm-specific proxies to measure the likelihood of over or under-investment following Biddle et al.(2009). The results are consistent with the main results that private firms are less likely to invest when liquidity is high, as measured by alternative aggregate proxies, and more likely to invest when the likelihood of over-investment is low. Finally, based on the literature documenting that private and public companies have different levels of financial reporting quality, which can affect investment efficiency, we re-test our hypotheses by including financial reporting quality proxies as control variables in the main regression model. These investigations further support our main results. 
Table 6. Results after controlling for Accounting Quality

\begin{tabular}{|c|c|c|c|c|}
\hline \multirow[b]{2}{*}{$\begin{array}{c}\text { Variables } \\
\text { (1) }\end{array}$} & \multicolumn{2}{|c|}{ Modified Jones Model } & \multicolumn{2}{|c|}{ D \& D Model } \\
\hline & $\begin{array}{l}\text { Coefficient } \\
\text { (2) }\end{array}$ & $\begin{array}{c}\text { t-value } \\
(3)\end{array}$ & $\begin{array}{c}\text { Coefficient } \\
(4)\end{array}$ & $\begin{array}{c}\text { t-value } \\
(5)\end{array}$ \\
\hline ULIST & 13.082 & $4.27^{* * * *}$ & 12.818 & $3.94^{* * * *}$ \\
\hline OVER_ULIST & -41.620 & $-6.19^{* * *}$ & -42.724 & $-5.81^{* * * *}$ \\
\hline OVER & 25.752 & $4.07^{* * * *}$ & 24.060 & $3.53^{* * *}$ \\
\hline$A B S D A$ & 6.412 & 0.46 & & \\
\hline ABSDA_OVER & 33.704 & 0.86 & & \\
\hline$D D$ & & & -27.362 & -1.15 \\
\hline DD_OVER & & & 92.854 & 1.51 \\
\hline $\operatorname{SIZ\overline {E}}$ & -3.403 & $-3.85^{* * *}$ & -3.401 & $-3.76^{* * *}$ \\
\hline$C F O$ & 50.902 & $6.12^{* * *}$ & 43.877 & $5.48^{* * * *}$ \\
\hline$A G E$ & -13.441 & $-8.89^{* * *}$ & -13.198 & $-8.31^{* * *}$ \\
\hline$D I V$ & -4.254 & $-2.26^{* *}$ & -5.216 & $-2.75^{* * *}$ \\
\hline LOSS & 4.085 & 1.61 & 2.051 & 0.80 \\
\hline CFOsale & -1.096 & -0.51 & -0.604 & -0.25 \\
\hline stdSALES & -8.986 & $-2.74^{* * *}$ & -7.094 & $-2.08^{* *}$ \\
\hline stdCFO & 56.867 & $2.98^{* * * *}$ & 63.861 & $3.23^{* * *}$ \\
\hline stdINV & 0.414 & $4.19^{* * * *}$ & 0.371 & $4.16^{* * *}$ \\
\hline$O P C$ & -1.823 & -1.04 & -1.565 & -0.94 \\
\hline Tangibility & -130.311 & $-21.76^{* * * *}$ & -125.731 & $-20.77^{* * * *}$ \\
\hline INDlev & -85.932 & $-3.02^{* * * *}$ & -77.997 & $-2.57^{* * *}$ \\
\hline Fixed Effect & \multirow{4}{*}{\multicolumn{2}{|c|}{$\begin{array}{c}\text { Year and Industry } \\
9,084 \\
0.158 \\
33.8^{* * *}\end{array}$}} & \multirow{4}{*}{\multicolumn{2}{|c|}{$\begin{array}{c}\text { Year and Industry } \\
7,556 \\
0.173 \\
30.8^{* * * *} \\
\end{array}$}} \\
\hline Observations & & & & \\
\hline adj R-square & & & & \\
\hline F-value & & & & \\
\hline F-test : & Coefficient & F-value & Coefficient & F-value \\
\hline $\begin{array}{l}\text { Joint significance } \\
(\text { ULIST+OVER_ULIST) }\end{array}$ & -28.538 & $65.31^{* * *}$ & -27.362 & $66.34^{* * * *}$ \\
\hline
\end{tabular}

This table presents the regression estimates of the model that examines the relation between private firms (ULIST) and total investment (Investment) based on the propensity-score matched sample. Columns 2 -3 provide the estimated coefficients using modified Jones model(Dechow et al., 1995) and columns $4-5$ represent the estimated coefficients using earnings quality measure (Francis et al.,2005). The model includes year and industry fixed effects based on based on two-digit Korean Standard Industry Codes. T-statistics are corrected for heteroskedasticity. ${ }^{* * *}, * *$, and * denote statistical significant at $1 \%, 5 \%$, and $10 \%$ levels respectively, based on twotailed test. See the Appendix for variable definitions.

This paper contributes to the literature on the important differences between private and public firms by showing that the investment efficiency of private firms is different from that of public firms. Prior studies document that private equity and public equity firms have different characteristics, such as financial reports quality, using a limited firm-year sample (Givoly et al., 2010; Beatty et al., 2002). This study provides additional evidence on the differences between private and public firms by comparing the investment behavior of privately held firms with that of public firms using large audited financial data of Korean firms. Additionally, this study focuses on agency perspectives such as information asymmetry, which plays an important role in determining the level of investment efficiency. Earlier studies document that financial reporting quality reduces agency costs, leading to an increase in investment efficiency (Cheng et al., 2013). This study provides additional evidence on the agency problem, which affects firms' investment decision.

\section{AUTHOR INFORMATION}

Dr. Keehwan Kim is a CPA working at Inil Accounting Corporation in Korea. He received his Ph.D. degree in Accounting from Sogang University in Korea. He has taught auditing and financial accounting at Sogang University and other schools for several years. His research focuses on strategic management, governance, investment efficiency and tax accounting. Keehwan Kim, Inil Accounting Corporation, Somang B/D, 11, Gangnam-daero 43gil, Seocho-gu, Seoul, 137-862, South KOREA. E-mail: kim4477@ gmail.com 
Ohjin, Kwon, Ph.D candidate and lecturer of Business Administration (BA) has been teaching at Bucheon University since 2014. He has been majoring the BA (Accounting) to achieve doctor degree at Sogang University since 2012. He received the Master of Financial Accounting degree from Sogang University. He also worked at trust company for 5 years. His research focuses on the investment efficiency, CSR, earnings management and corporate governance. Ohjin Kwon, School of Business, Sogang University, 35 Baekbumro, Mapogu, Seoul, 121-742, South Korea. E-mail: arbiter97@ hanmail.net (Corresponding author).

\section{REFERENCES}

Armstrong, C., A. Jagolinzer, and D. Larcker. (2010). Chief executive officer equity incentives and accounting irregularities. Journal of Accounting Research, 48, 225-271.

Ashbaugh-Skaife, H., D. Collins, W. Kinney, and R. LaFond. (2008). The effect of SOX internal control deficiencies and their remediation on accrual quality. The Accounting Review, 83, 217-250.

Baker, M. (2000). Career Concerns and Staged Investment: Evidence from the Venture Capital Industry. Working paper. Harvard Business School.

Baker, M., J. Stein, and J. Wurgler. (2003). When does the market matter? Stock prices and the investment of equitydependent firms. Quarterly Journal of Economics, 118, 969-1005.

Ball, R., and L. Shivakumar. (2005). Earnings Quality in U.K. private firms: Comparative Loss Recognition Timeliness. Journal of Accounting and Economics, 39(1), 83-128.

Berzins, J., Ø. Bøhren, and P. Rydland. (2008). Corporate finance and governance in firms with limited liability : Basic characteristics. Working paper, Norwegian School of Management.

Beatty, A., B. Ke, and K. Petroni. (2002). Earnings management to avoid earnings declines across publicly and privately held banks. The Accounting Review, 77(3), 547-570.

Beatty, A., and D. Harris. (1998). The Effects of Taxes, Agency Costs and Information Asymmetry on Earnings Management : A Comparison of Public and Private Firms. Reviews of Accounting Studies, 3, 299-326.

Bhide, A. 1993. The hidden cost of stock market liquidity, Journal of Financial Economics, 34, 34-51.

Burgstahler, D.C., L. Hail, and L. Christian. (2006). The Importance of Reporting Incentives: Earnings Management in European Private and Public Firms. The Accounting Review, 81(5), 983-1016.

Bertrand, M., and S. Mullainathan. (2003). Enjoying the Quiet Life? Corporate Governance and Managerial Preferences. Journal of Political Economy, 111, 1043-1075.

Blanchard, O., F. Lopez-de-Silanez, and A. Shleifer. (1994). What Do Firms Do With Cash Windfalls? Journal of Financial Economics, 36, 337-360.

Biddle, G., and G. Hilary. (2006). Accounting quality and Firm-level Capital Investment. The Accounting Review, 83 (3), 665-703.

Biddle, G., G. Hilary, and R. Verdi. (2009). How does financial reporting quality relate to investment efficiency? Journal of Accounting and Economics, 48, 112-131.

Chen, F., O. Hope, Q. Li, and X. Wang. (2011). Financial Reporting Quality and Investment Efficiency of Private Firms in Emerging Markets. The Accounting Review, 86(4), 1255-1288.

Cheng, M., D. Dhaliwal, and Y. Zhang. (2013). Does investment efficiency improve after the disclosure of material weaknesses in internal control over financial reporting? Journal of Accounting and Economics, 56, 1-18.

Dechow, P., and I. Dichev. (2002). The Quality of Accruals and Earnings: The Role of Accrual Estimation Errors. The Accounting Review, 77(4), 35-59.

Dechow, P., R. Sloan, and A. Sweeney. (1995). Detecting earnings management. The Accounting Review, 70, 193-225.

Francis, J., R. Lafond, P. Olsson, and K. Schipper. (2005). The market pricing of accrual quality. Journal of Accounting and Economics, 39(2), 295-327.

Givoly, D., C. Hayn, and S. Katz. (2010). Does public ownership of equity improve earnings quality? The Accounting Review, 85(1), 195-225

Hope. O., W. Thomas, and D. Vyas. (2013). Financial Reporting Quality of U. S. Private and Public Firms. The Accounting Review, 88(5), 1715-1742.

Jensen, M., and W. Meckling. (1976). Theory of the Firms : Managerial Behavior, Agency Costs and Ownership Structure. Journal of Financial Economics, 3(4), 305-360.

Jensen, M. (1986). Agency Costs of Free Cash Flow, Corporate Finance, and Takeovers. American Economic Review, 76, 323-329. 
Klein, A. (2002). Audit committee, board of director characteristics, and earnings management. Journal of Accounting and Economics, 33, 375-400.

Lambert, R., C. Leuz, and R. Verrecchia. (2007). Accounting information, disclosure and the cost of capital. Journal of Accounting Research, 45, 385-420.

Lawrence, A., M. Minutti-Meza, and P. Zhang. (2011). Can Big 4 versus Non-Big 4 Differences in Audit-Quality Proxies Be Attributed to Client Characteristics? The Accounting Review, 86(1), 259-286.

McNichols, M., and S. Stubben. (2008). Does earnings management affect firms' investment decisions? The Accounting Review, 83, 1571-1603.

Myer, S. (1977). Determinants of Corporate Borrowing. Journal of Financial Economics, 5, 147-175.

Myer, S., and N. Majluf. (1984). Corporate financing and investment decisions when firms have information that investors do not have. Journal of Financial Economics, 13, 187-221.

Opler, T., L. Pinkowitz, R. Stulz, and R. Williamson. (1999). The Determinants and Implications of Corporate Cash Holdings. Journal of Financial Economics, 52, 3-46.

Richardson, S. (2006). Over-investment of free cash flow. Review of Accounting Studies, 11, 159-189.

Stein, J. C. (2003). Agency, Information and Corporate Investment. Handbook of the Economics of Finance, 1(1), 111-165.

Stiglitz, J., and A. Weiss. (1981). Credit rationing in markets with imperfect information. American Economic Review, 71, 393-401.

Teoh, S., T. Wong, and G. Rao. (1998). Are accruals during initial public offerings opportunistic? Review of Accounting Studies, 31,75-208.

Van Tendeloo, B., and A. Vanstraelen. (2008). Earnings management and audit quality in Europe: Evidence from the private client segment market. European Accounting Review, 17(3), 447-469.

Welch, I. (1989). Seasoned offerings, imitation costs, and the underpricing of initial public offerings. The Journal of Finance, 44(2), 421-449. 


\title{
APPENDIX: VARIABLE DEFINITIONS
}

\author{
Dependent Variables

Investment $=$ the sum of $\mathrm{R} \& \mathrm{D}$ expenditures and capital expenditure multiplied by 100 and scaled by \\ lagged PPE. \\ Capex $=$ capital expenditures multiplied by 100 and scaled by lagged PPE. \\ Non-Capex $=\mathrm{R} \& \mathrm{D}$ expenditures multiplied by 100 and scaled by lagged PPE. \\ Ownership structure variables \\ ULIST $=$ an indicator variable that takes the value of 1 if the firm is a private firm, and 0 otherwise.
}

Over-investment proxies

\begin{tabular}{ll}
\hline OVER $=$ & $\begin{array}{l}\text { a ranked variable based on the average rank of a ranked (re-scaled from zero to one } \\
\text { deciles) measure of cash and leverage, as in Biddle et al.(2009). Leverage is multiplied by } \\
\text { minus one before ranking so that both variables are increasing in the likelihood of } \\
\text { over-investment. } \\
\text { a ranked variable based on the unexplained industry-year investment, as in Biddle et } \\
\text { al.(2009). Specifically, in each industry-year we measure aggregate investment and } \\
\text { regress industry-year investment on industry-year sales growth. We then rank the }\end{array}$ \\
residual from this model into deciles and re-scale from zero to one. \\
a ranked variable based on the unexplained aggregate investment rate for all firms in the \\
economy, as in Biddle et al.(2009). Specifically, in each year we measure the average \\
investment in the economy and regress aggregate investment on aggregate sales growth. \\
We then rank the residual from this model into deciles and re-scale from zero to one.
\end{tabular}

Financial reporting quality

$\begin{array}{lll}A B S D A & = & \text { the absolute value of residuals from the modified Jones model(Dechow et al., 1995). } \\ D D & = & \text { the absolute value of residuals from the modified Dechow and Dichev(2002) } \\ & \text { model(Francis et al., 2005). }\end{array}$

Control variables

\begin{tabular}{|c|c|c|}
\hline$A G E$ & $=$ & the natural log of firm age. \\
\hline $\mathrm{CFO}$ & $=$ & the cash flow from operations deflated by current total assets. \\
\hline CFOsale & $=$ & the ratio of CFO to sales. \\
\hline DIV & $=$ & an indicator variable that takes the value of 1 if the firm paid a dividend, and 0 otherwise. \\
\hline INDlev & $=$ & the average leverage for industries. \\
\hline LOSS & $=$ & $\begin{array}{l}\text { an indicator variable that takes the value of } 1 \text { if net income is negative, and } 0 \text { otherwise. } \\
\text { the natural log of receivables to sales plus inventory to COGS multiplied by } 360 \text {. }\end{array}$ \\
\hline$O P C$ & $=$ & changes in sales scaled by lagged sales. \\
\hline SalesGrowth & $=$ & the natural $\log$ of total assets. \\
\hline SIZE stdCFO & $=$ & $\begin{array}{l}\text { standard deviation of the cash flow from operations deflated by average total assets from } \\
\text { t- } 4 \text { to } t \text {. }\end{array}$ \\
\hline stdINVEST & $=$ & $\begin{array}{l}\text { standard deviation of the investment deflated by average total assets from } t-4 \text { to } t \text {, the } \\
\text { investment is defined by the sum of R\&D expenditures and PPE multiplied by } 100 \text { and } \\
\text { scaled by lagged total assets. }\end{array}$ \\
\hline stdSALES & $=$ & standard deviation of the sales deflated by average total assets from t-4 to $t$. \\
\hline Tangibility & $=$ & the ratio of PPE to total assets. \\
\hline
\end{tabular}

